\title{
Comparative Study of Cranial Capacity of the Non-tribal with Korku Tribal Population of Madhya Pradesh, India
}

\author{
Estudio Comparativo de la Capacidad Craneal de Población \\ No-Tribal con la Tribal Korku de Madhya Pradesh, India \\ "Vineet Kumar Gohiya; ${ }^{* *}$ Sudha Shrivatava $\&{ }^{* * *}$ Sarita Gohiya
}

GOHIYA, V. K.; SHRIVATAVA, S. \& GOHIYA, S. Comparative study of cranial capacity of the Non-tribal with Korku tribal population of Madhya Pradesh, India. Int. J. Morphol., 30(1):263-265, 2012.

SUMMARY: Knowledge of cranial capacity is useful in differentiation of racial and sexual differences, which indirectly reflects the brain volume in different populations. Most of these studies have been done on the dry skulls using linear dimensions. Only few studies have been done on living subjects. The aim of this study was to compare cranial capacity of particular age group of Korku tribe \& Non-tribal population of Madhya Pradesh a state of India. This study was carried on 800 healthy volunteer of 20 - 25 year-old age group (in which each 400 males and females) in Korku tribe and Non-tribal population of Madhya Pradesh state of India, by using linear dimensions of head (Lee Pearson's formula). The mean cranial capacity and SD in Non-tribal males and Non-tribal females were $1380.5 \pm 94.6 \mathrm{cc}$ and $1188.7 \pm 91.1$ cc, respectively. The mean cranial capacity and SD in Korku males and Korku females were $1212.2 \pm 62.0 \mathrm{cc}$ and $1047.4 \pm 72.4$, cc respectively. This study has shown a significant $(\mathrm{p}<0.05)$ difference between the same gender populations of Korku tribe and Non-tribal population, with the absolute values being higher in Non-tribal group than in Korku tribe group.

KEY WORDS: Anthropometry; Cranial capacity; Skull; Sex; Tribe.

\section{INTRODUCTION}

Knowledge of cranial capacity is useful in differentiation of racial and sexual differences either a dry skull or of a living subject and may be important to the study and comparison of the crania of populations with various fundamental differences like geographic, ethnic, dietary, environmental etc (Manjunath, 2002a). Cranial capacity, which is in close correlation with brain volume, reflects the racial characteristics and this has been thought to be one of commonest item in physical anthropological studies (Hwang et al., 1995; Manjunath, 2002a). One of the most satisfactory methods for measuring cranial capacity of a dry skull with the help of water poured into balloon which introduced the cranial cavity through a foramen magnum (Manjunath, 2002b; Acer et al., 2007). Most of those available studies have been done on dry skulls using linear dimensions, packing methods or occasionally radiological methods. Only a few studies have been done on living subjects (Golalipour et al., 2005; Acer et al.; Nooranipour \& Farahani, 2008; Gohiya et al., 2010a, 2010b). Although a few studies on the estimation of cranial volume do exist in the Indian literature, these studies are based on examination of macerated skulls
(Manjunath, 2002b; Shukla, 1966; Routal et al., 1984) and living subjects (Gohiya et al., 2010a, 2010b). An analysis of cranial capacity exposes another aspect of growth and development; and permits critical evaluation of unusually large, small or misshapen skulls (Haack \& Meihoff, 1971). Hence an attempt has been made in the present study to compare the cranial capacity of the Non-tribe and Korku tribe populations in Madhya Pradesh state of India.

\section{MATERIAL AND METHOD}

This study was carried out on four hundred healthy subject of 20 - 25 years old (200 males and 200 females) Non-tribal individuals and four hundred healthy Korku tribe (200 males and 200 females) of Madhya Pradesh state of the India, during 2005 - 2006. All the measurements were taken with the subjects sitting in chair, in relaxed condition and head in the anatomical position. In each subject following linear dimensions of the head were measured. 
- Maximum head length (L) (Glabella - Inion length).

- Maximum head breadth (B) (measured between parietal eminences). $1 \& 2$ measured with spreading caliper.

- Head height $(\mathrm{H})$ (external acoustic meatus to the highest point of the vertex) using sliding caliper and an auricular head spanner.

Each measurement was taken to the nearest millimeter at least three times and the average was considered for calculation. The magnitude of cranial capacity was calculated using Lee Pearson's formula (given by Williams et al., 1995; Manjunath, 2002a).

- Males: 0.000337(L-11) (B-11) (H-11) +406.01cc

- Females: 0.000400(L-11) (B-11) (H-11)+206.60cc

The data of each person was recorded and analyzed by SPSS 17 and MS Excel 2007. For comparison of the mean of cranial capacity ' $\mathrm{t}$ ' test was used.

\section{RESULTS}

The mean, SD of head length, head breadth and head height of both sexes in Non-tribal group are mentioned in Table I. The mean cranial capacity and SD in males and females were $1380.524 \pm 94.633$ $\mathrm{cc}$ and $1188.758 \pm 91.164 \mathrm{cc}$ respectively. There was a significant difference between genders $(\mathrm{p}<0.05)$.

The mean, SD of head length, head breadth and head height of both sexes in Korku tribe groups are mentioned in Table II. The mean cranial capacity and SD in males and females were 1212.273 \pm 62.006 $\mathrm{cc}$ and $1047.421 \pm 72.416 \mathrm{cc}$ respectively. There was a significant difference between genders $(\mathrm{p}<0.05)$.

This study has shown a significant $(\mathrm{p}<0.05)$ difference between the same gender subjects of Korku tribe and Non-tribal population,

Table I. Showing various parameters of the head of 20 - 25 yrs. old Non-tribal group of Madhya Pradesh state of India.

\begin{tabular}{lcccc}
\hline \multirow{2}{*}{ Different parameters } & \multicolumn{2}{c}{ Male } & \multicolumn{2}{c}{ Female } \\
\cline { 2 - 5 } & Mean & SD & Mean & SD \\
\hline Maximum head length $(\mathrm{mm})$ & 191.270 & 6.903 & 178.720 & 5.577 \\
Maximum head breadth $(\mathrm{mm})$ & 145.615 & 5.908 & 138.740 & 6.123 \\
Head height $(\mathrm{mm})$ & 130.025 & 7.206 & 125.475 & 6.023 \\
\hline
\end{tabular}

Table II. Showing various parameters of the head of 20 - 25 yrs. old Korku tribe group of Madhya Pradesh state of India.

\begin{tabular}{lcccc}
\hline \multirow{2}{*}{ Different parameters } & \multicolumn{2}{c}{ Male } & \multicolumn{2}{c}{ Female } \\
\cline { 2 - 5 } & Mean & SD & Mean & SD \\
\hline Maximum head length $(\mathrm{mm})$ & 182.215 & 4.873 & 175.005 & 5.594 \\
Maximum head breadth $(\mathrm{mm})$ & 135.315 & 4.640 & 130.320 & 5.006 \\
Head height $(\mathrm{mm})$ & 123.320 & 5.362 & 118.315 & 5.263 \\
\hline
\end{tabular}

264 with the absolute values being higher in Non-tribal group than in Korku tribe group.

\section{DISCUSSION}

In this study estimated cranial capacity from Non-tribe group in males and females were $1380.524 \pm 94.633 \mathrm{cc}$ and $1188.75 \pm 91.16 \mathrm{cc}$ respectively and in Korku tribe group in males and females were $1212.273 \pm 62.006 \mathrm{cc}$ and $1047.421 \pm 72.416 \mathrm{cc}$ respectively. Estimated cranial capacity in this study of both Non-tribe and Korku tribe groups are lower than Mugla University students, Mugla Turkey (Acer et al.). Estimated cranial capacity of Korku tribe group in current study is closely similar to the Bheel tribe group from the same geographic area, but cranial capacity of Non-tribe group is significantly higher than Bheel tribe group (Gohiya et al., 2010a, 2010b).

Hooton (1926) reported that the racial characteristics are best defined in the skull, cranial capacity being one of the most important parameter for determining the racial difference.

Hwang et al. observed that the mean cranial capacity and SD in an adult Korean males and females were $1470 \pm 107 \mathrm{cc}$ and $1317 \pm 117$ cc respectively. Manjunath et al. (2002a) observed that the mean cranial volume and SD in males and females were $1152.813 \pm 279.16 \mathrm{cc}$ and $1117.82 \pm 99.09 \mathrm{cc}$ respectively. Another research in North of Iran by Golalipour et al. reported the mean and SD of cranial capacity in Turkman males $1420.6 \pm 85 \mathrm{cc}$ and in $1227.2 \pm 120 \mathrm{cc}$ in females. The mean and SD of cranial capacity in native Fars males $1369 \pm 142 \mathrm{cc}$ and $1215.8 \pm 125$ cc in female.

According to Acer et al. the mean and SD of cranial capacity in the male and female students of the Mugla university, Mugla, Turkey were $1411.64 \pm 118.9 \mathrm{cc}$ and $1306 \pm 162.9 \mathrm{cc}$ respectively. There was significant difference between genders $(p<0.05)$. Nooranipour \& Farahani observed that cranial capacity and brain weight in an adult Iranian male were $1343.45 \pm$ $102.37 \mathrm{cc}$ (mean \pm SD) and $1390.47 \pm 105.95 \mathrm{gm}$ (mean \pm SD) respectively. Cranial capacity and brain weight in an adult Iranian female were 
$1163.02 \pm 115.76 \mathrm{cc}($ mean $\pm \mathrm{SD})$ and $1203 \pm 119.8 \mathrm{gm}$ (mean $\pm \mathrm{SD}$ ) respectively. Gohiya et al. (2010a) observed that mean and SD in males and females were $1380.52 \pm$ $94.63 \mathrm{cc}$ and $1188.75 \pm 91.16 \mathrm{cc}$ respectively in Madhya Pradesh geographic of the India. There was a significant difference between sexes ( $\mathrm{p}<0.05)$. Gohiya et al. (2010b) observed that the mean cranial capacity and SD in Bheel tribe males and females were $1212.33 \pm 72.323 \mathrm{cc}$ and $1096.26 \pm 88.825$ cc respectively in Madhya Pradesh geographic of the India. There was significant difference between genders $(\mathrm{p}<0.05)$.

Cranial capacity indirectly reflects the volume of brain, which is affected by sex, race, ethnic, geographical, biological and ecological factors. We also conclude that cranial capacity and brain volume is being affected by sex and race of the population as studied here in the geographic area of India.

GOHIYA, V. K.; SHRIVATAVA, S. \& GOHIYA, S. Estudio comparativo de la capacidad craneal de población no-tribal con la tribal Korku de Madhya Pradesh, India. Int. J. Morphol., 30(1):263-265, 2012.

RESUMEN: Conocer la capacidad craneal es útil para discriminar diferencias raciales y sexuales, la cual indirectamente refleja el volumen del cerebro en diferentes poblaciones. La mayoría de estos estudios se han realizado en cráneos secos con dimensiones lineales pero escasas investigaciones se han realizado en sujetos vivos. El objetivo de este trabajo fue comparar la capacidad craneal de un grupo etáreo de la tribu Korku y población no tribal de Madhya Pradesh, un estado de la India. Este estudio fue realizado en 800 voluntarios sanos, entre 20 - 25 años de edad (400 hombres y 400 mujeres) de la tribu Korku y población no tribal de Madhya Pradesh de la India, mediante el uso de las dimensiones lineales de la cabeza (fórmula de Lee Pearson ). La capacidad craneal media y DE en la población no tribal para hombres y mujeres fueron 1380,5 $\pm 94,6$ cc y $1188,7 \pm 91,1 \mathrm{cc}$, respectivamente. La capacidad craneal media y DE en los hobres y mujeres Korku fueron $1212,2 \pm 62,0$ cc y 1047,4 $\pm 72,4$ cc, respectivamente. Este estudio ha mostrado una diferencia significativa $(\mathrm{p}<0,05)$ entre las poblaciones no tribal y la tribu Korku del mismo sexo, con los valores absolutos mayores en el grupo no tribal en comparación con el grupo de la tribu Korku.

\section{PALABRAS CLAVE: Antropometría; Capacidad craneal; Cráneo; Sexo; Tribu.}

\section{REFERENCES}

Acer, N.; Usamaz, M.; Tugay, U. \& Erteki'n, T. Estimation of cranial capacity in 17-26 years old university students. Int. J. Morphol., 25:65-70, 2007.

Gohiya, V. K.; Shrivatava, S. \& Gohiya, S. Estimation of cranial capacity in 20-25 year old population of Madhya Pradesh, a state of India. Int. J. Morphol., 28:1211-4, 2010a.

Gohiya. V. K. A Comparative Study of Cranial Capacities in Bheel Tribe \& Non-Tribal Population in Age Group 20-25 Years Old in Madhya Pradesh. Forensic Med. Toxicol., 10:90-2, 2010 b.

Golalipour, M. J.; Jahanshaei, M. \& Haidari, K. Estimation of cranial capacity in 17-20 years old in South East of Caspian Sea Border (North of Iran). Int. J. Morphol., 23:301-4, 2005.

Haack, D. C. \& Meihoff, E. C. A method for estimation of cranial capacity from cephalometric roentgenograms. Am. J. Phys. Anthropol., 34:447-52, 1971.

Hooton, E. A. A method of racial analysis. Science, 44:256, 1926.

Hwang, Y. I.; Lee, H. K.; Choi, B. Y.; Lee, K. S.; Sir, W. S.; Kim, H. J., et al.. Study on the Korean Adult Cranial Capacity. J. Korean Med. Sci., 10:239-42, 1995.

Manjunath, K. Y. Estimation of cranial volume in dissecting room cadavers. J. Anat. Soc. India, 51:168-72, 2002b.
Manjunath, K. Y. Estimation of cranial volume - an overview of methodologies. J. Anat. Soc. India, 51:85-91, 2002a.

Nooranipour, M. \& Farahani, R. M. Estimation of cranial capacity and brain weight in 18-22-year-old Iranian adults. Clin. Neurol. Neurosurg., 110:997-1002, 2008.

Routal, R. V.; Pal, G. P. \& Bhagwat, S. S. Relationship between endocranial volume and the area of the foramen magnum. $J$. Anat. Soc. India, 33:145-9, 1984.

Shukla, A. P. A study of cranial capacity \& cranial index of Indian skull. J. Anat. Soc. India., 15:31-5, 1966.

Williams, P. L.; Bannister, L. H.; Berry, M. M. Collins, P.; Dyson, M.; Dussek, J. E. \& \& Ferguson, M. W. J. Gray's Anatomy: The anatomical basis of medicine and surgery. 38th Ed. London, Churchill Livingstone, 1995.

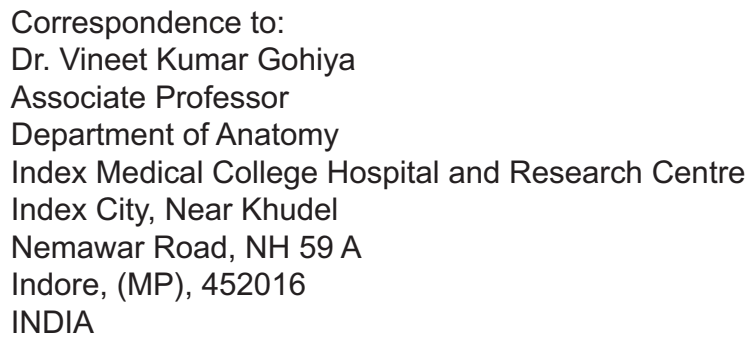

Email: vkgohiya@gmail.com

Received: 30-05-2011

Accepted: 02-08-2011 